\title{
Charlie Gladstone, rentier or entrepreneur? A case study of contemporary 'aristocratic enterprise'.
}

GRANT, G. and SMITH, R. 


\section{Charlie Gladstone, rentier or entrepreneur? A case study of contemporary 'Aristocratic Enterprise'}

The International Journal of Entrepreneurship and Innovation 202I, Vol. 22(3) 203-2I 2

(C) The Author(s) 202I

\section{(c) (1)}

Article reuse guidelines: sagepub.com/journals-permissions DOI: | 0.1 | $77 /|465750320984| 86$ journals.sagepub.com/home/iei (S)AGE

\author{
Graham Grant \\ Robert Gordon University, UK
}

\author{
Rob Smith (1) \\ Independent Scholar
}

\begin{abstract}
Context, including social class is an emerging topic of interest in entrepreneurship studies. According to prevailing orthodoxy, to be upper-class is to be anti-enterprise. Aristocrats are defined through their ownership of land and rentier status and portrayed as conservative being focused on stewardship of their estates, rather than engaging with enterprising activities. This case challenges this traditional perception arguing that aristocrats can pursue an entrepreneurial approach to stewardship in contrast with traditional, low-risk, estate management. The focus is upon aristocrat Charlie Gladstone to explore this phenomenon. Charlie is both rentier and serial entrepreneur who engages his entrepreneurial efforts on the economic reinvigoration of his estates and expanding portfolio of entrepreneurial ventures. The case demonstrates that the enriched human, social and economic capital available to the upper-class can be exploited in an entrepreneurial manner.
\end{abstract}

\title{
Keywords
}

Aristocracy, entrepreneurship, place, posh-preneurs, rentiers, social class

\section{Learning outcomes}

By engaging in this case study, students will be able to better understand the intersections between class context and entrepreneurship. Moreover:

1. This case extends existing theoretical constructions of entrepreneurship and class by demonstrating the practical application of entrepreneurship outside its traditional domain. These include social class, social mobility and entrepreneurial identity.

2. This case and analysis demonstrate that the traditional model of upper-class entrepreneurship and estate management is not the only model available. New business models can incorporate old fashioned rentier-capitalism and stewardship with a more entrepreneurial approach to land management and the leverage of aristocratic social capital with entrepreneurial social capital.

3. Membership of the upper-class should not disqualify the upper-class from being an entrepreneur. Social class is just another context.

\section{Case narrative}

This case was compiled from 'In-depth' interviews by the first author. ${ }^{1}$ In this case we utilise the seminal, universal definition of entrepreneurship posited by Alistair Anderson as 'The creation and extraction of value from an environment' (Anderson, 1995) which fits all contexts and social classes. The sociological context of 'social class' was posited by Max Weber to refer to a group of people with similar levels of wealth and status (Weber, 2013). Class is socially constructed in that social classes require to be

\section{Corresponding author:}

Rob Smith, University of the West of Scotland, Gardener Building, Paisley PAI 2BE, UK.

Email: r.smith-a@hotmail.com 
maintained and legitimated by all societal members. In the UK, there are a number of ascending social classes including the underclass, the working class, the middle-class and the upper-class or aristocracy (Smith et al., 2014). The social class of an entrepreneur influences their individual and collective 'entrepreneurial identities', 'social capital' (Bourdieu, 1997) and in particular 'entrepreneurial social capitals' (Firkin, 2003; Jones et al., 2019a, 2019b). In this context, entrepreneurial identity relates to how an individual chooses to manifest accepted entrepreneurial ideology and semiotic imagery in their narratives and actions. Context is an emerging topic of interest, particularly in relation to entrepreneurial identities (Gaddefors and Anderson, 2018; Jones et al., 2019a, 2019b) and how these are perceived in relation to social class.

In the early entrepreneurship literature, there was an undue focus placed on the lone, heroic entrepreneur from 'humble beginnings' albeit this myth has been debunked by Drakopoulou Dodd and Anderson (2007). Latterly theories have concentrated instead on the importance of social capital, embeddedness and context (Anderson and Jack, 2000). At the heart of this contextual turn is the criticism of entrepreneurship as an individual endeavour. Nevertheless, social class is an such under-researched context which this case addresses. In a UK context, the class-based literature of entrepreneurship overly focuses upon the theoretical standpoints of the 'working-class' and the 'middle-class' entrepreneurs (Goffe and Scase, 2015) to the exclusion of the 'upper-class' variety. According to Martinelli (2004) entrepreneurship cannot be fully understood without reference to its sociocultural and socio-political institutional contexts. These influence entrepreneurial attitudes and motivations and the resources mobilised. The higher one's social class the more resources and capitals one can mobilise (ala, Anderson and Miller, 2003). Yet, according to prevailing orthodoxy, to be upper-class and aristocratic is supposedly to be anti-enterprise (Thompson, 2001).

Although perceptions of class differ across cultures and time, the literature examining the British upper-class remains relatively static (see Cannadine, 1977; Grant, 2020; Mee, 1975; Mingay, 1963; Thompson, 1963, 2001). Notwithstanding this, a sparse literature on class and entrepreneurship reveals a gap in knowledge. Members of the peerage and landed gentry are mainly defined through their ownership of land and their ability not to work, instead being able to live off rentier income (Pollin, 2007; Standing, 2017). Accordingly, the upper-class are portrayed as conservative and focused on stewardship of their estates, rather than engagement with enterprising activities (see Gill et al., 2010).

Consequentially, this case examines the underresearched topic of 'Aristocratic Enterprise' (Mee, 1975) and 'posh-preneurship' (Fellows, 2008) in a UK context by presenting the story of Charles Angus
Gladstone, great-great grandson of Liberal Prime Minister, William Gladstone, to explore this phenomenon within the context of existing literature and contemporary rural practice (see Grant, 2020). Charlie as he likes to be known, the 8th Baronet of Fasque and Balfour is a serious, serial entrepreneur who has overseen an expanding portfolio of entrepreneurial ventures and the cultural renewal and economic reinvigoration of his 'Estates' - Fasque and Glen Dye in Kincardineshire, Scotland and Hawarden in Flintshire, Wales. The latter consists of both rural, farming land and castles, the village of Hawarden, crossing over between rural and village, and providing a blurring of both estate boundaries and village identity. Although often cash-poor, large landholdings and considerable stocks of human and social capital enables the upperclasses to become successful entrepreneurs (Thompson, 2001). However, their traditional business practices: estate management, farming and land and property rental, are relatively low-risk and conservative in outlook and practice. As with other niche forms of entrepreneurship, research access to the upper-class is problematic. ${ }^{2}$

A secondary theoretical context is that of 'Social Mobility' and 'Inequality' (Lippmann et al., 2005). Lippmann et al. conclude that entrepreneurship can be a source of achieving and maintaining socio-economic mobility and that there is a definite relationship between inequality and access to entrepreneurial opportunity. This case seeks to identify whether this traditional perception remains valid, or to discover whether contemporary aristocrats and members of the landed-gentry pursue an entrepreneurial approach to the exploitation and renewal of their land in contrast with traditional, low-risk, aristocratic estate management. The key touch points in the literature relate to class-based theories of entrepreneurship and the role of entrepreneurship in developing entrepreneurial identity and social capital and mobility.

\section{Narrating the case}

To understand Charlie's aristocratic and entrepreneurial social capital (Firkin, 2003) one has to understand family history and heritage. The Baronetcy of Fasque and Balfour is situated in the Scottish county of Kincardineshire. The title was created in 1846 for Charlie's great-great-great Grandfather, Scottish businessman John Gladstone. Charlie's great-great grandfather, William Ewart, was the famous Liberal Prime Minister from the 1860s-1890s, positioning Charlie within the 'Aristocracy' and 'landed gentry'. ${ }^{3}$ The family have had a long connection to landowning, business and politics. Charles Angus Gladstone was born on 11 April 1964. His father Sir Erskine William Gladstone lived at Hawarden.

Charlie was educated at Eton College and Worcester College, Oxford where he read geography. In his own words, he '... wasn't a dedicated scholar, graduating with 
Table I. Details of the Gladstone entrepreneurial portfolio.

\begin{tabular}{|c|c|}
\hline $\begin{array}{l}\text { Pedlars mail order catalogue } \\
\text { www.pedlars.com }\end{array}$ & $\begin{array}{l}\text { This has expanded into a wider brand with a store in Nottinghill, London and one at Hawarden } \\
\text { Castle. }\end{array}$ \\
\hline $\begin{array}{l}\text { Charliegladstone.com } \\
\text { The Mavericks Podcasts } \\
\text { The Good Life Talks }\end{array}$ & $\begin{array}{l}\text { This is an associated branded website which Charlie uses to advertise his enterprises and it also acts } \\
\text { as personal webspace for his blogging activities. It hosts The Good Life Talks and Mavericks } \\
\text { podcasts. }\end{array}$ \\
\hline $\begin{array}{l}\text { Glen Dye Cabins and } \\
\text { Cottages. }\end{array}$ & This venture is a glamping experience with cabins and luxury cottages to rent. \\
\hline Hawarden Castle. & $\begin{array}{l}\text { This ancestral, stately home is a country house and farm. It hosts a 'farm shop' and 'the Pavilion' party } \\
\text { rental space. There are } 22 \text { rented farms on the estate. }\end{array}$ \\
\hline $\begin{array}{l}\text { Pedlars Guide to the Great } \\
\text { Outdoors. }\end{array}$ & This is a book covering the Gladstones philosophy to rural living and extols the Pedlars virtues. \\
\hline The Glynne Arms & This is the village pub in Hawarden village. \\
\hline The Good Life Experience & $\begin{array}{l}\text { An annual festival to highlight country living and the good life. Revenue is raised via ticket sales and } \\
\text { the sale of goods. }\end{array}$ \\
\hline Fettercairn Castle & Wedding Venue business. \\
\hline
\end{tabular}

a third-class degree, but while there developed an interest in town planning and the social aspects of geography'. His university education helped develop his keen sense of showmanship, through involvement in the theatre; and also, his entrepreneurial skills. A university education provides an ideal context for the intellectual and theoretical aspects of entrepreneurial learning and also provides a practical aspect in relation to situated learning too (Pittaway and Cope, 2007). Studying in the early 1980s, he and two friends ran a nightclub on Monday nights. Most weeks, they all made $£ 300$ profit, which he kept in his back pocket. Gladstone thus developed his analytic and intellectual skills as well as his ability to theorise but simultaneously his extra-curricular entrepreneurial activities honed his entrepreneurial skills. At University he developed an interest in land economy and management which influenced his business philosophy. These examples demonstrate situated entrepreneurial learning.

Intriguingly, he talks of the machinations of his Eton education when he arrived there, he was a nervous, not terribly academic child. His peers include former prime minister, David Cameron, and the former Mayor of London and current Prime Minister, the iconoclastic Boris Johnson. The atmosphere helped inculcate a sense of entitlement and confidence, and an ability to make things happen. He talks of a slightly sinister 'Machiavellian atmosphere where you will win, however it is, you will win.', and it is that attitude that he ascribes to both his own and his peers' success albeit whether that attitude is synonymous with being upper-class is debatable. Charlie admits that he doesn't know how to distinguish between middle and upper classes anymore, although he is aware of a shift in attitudes between his father's generation and his. On leaving university he became involved in the music industry as an impresario, promoter and manager of bands before becoming disillusioned with the lifestyle.
Charlie married Caroline Mali in 1988. She is central to his entrepreneurial identity and entrepreneurial social capital (Firkin, 2003) and is active in business ventures. After leaving university and during the early years of his marriage, they moved back to live in the ancestral family seat to provide a better life for their family. The couple have six children. ${ }^{4}$ The bulk of the family wealth was/is based around the ownership of the estates. Charlie runs the estates himself commuting between them and his family home in London, where his wife and youngest daughter live. However, while waiting for his inheritance and his elevation to the Baronetcy. They started a business together - Pedlars which is a mail order catalogue of clothing, furniture and 'bric-a-brac' associated with country life and living. This lucrative business underpins their expanding empire and entrepreneurial ventures. Table 1 details their portfolio:

The enterprises most closely associated with Charlie are the Pedlars brand, and the Hawarden activities. Pedlars is as a lifestyle company, selling home accessories both new and vintage, through website and retail outlets (Burt, 2010). To raise working capital for entrepreneurial adventuring Gladstone sold a $60 \%$ stake to a private equity firm who specialise in niche online retailers, such as Notonthehighstreet. com. Charlie talked of how they leverage lifestyle as a branding device for the Pedlars business, but also ironically how the very aspects of country life that served so well for the promotion of the business, make the functional aspects of running the enterprise so difficult.

\section{Entrepreneurial stewardship and the family fortune}

Charlie is passionate about running his businesses and being an entrepreneur. The conversation is littered with references to professionalism and doing things properly. He developed his personal taxonomy of landowners as entrepreneurs. Firstly, there is the traditional, agriculture- 
college educated farming landowners content with the status quo and doing what they know best. Secondly, there are 'dreamers' who 'do' a 'crap' farm shop, with a visitor every 3 hours and eight out-of-date cabbages for sale. The third type do amazing things (e.g. Charles March at the Goodwood estate). This is the group Charlie identifies with. To appreciate Charlie as an entrepreneurial and innovative Rentier one must examine his stewardship activities.

The Glen Dye Estate: The initial attraction here was a desire to raise a family. The family home at Glen Dye is the seat of empire. Various steading buildings have been converted into thoughtful, modern houses, rented out to oil workers and holiday makers. Hunkering above the steadings is a large quasi-industrial building, housing the wood-fired boiler that heats the whole development. Designed by Glasgow-based architecture firm NORD, the office has the empty feeling of a newly occupied building. However, the furnishings consist of a battered Victorian desk draped in a Union Jack, oversized farmhouse kitchen table doubling service as a boardroom table, mixed with quirky, modern pieces of lighting, suggest this is not an estate preserved in aspic.

$\mathrm{He}$ is critical of how the estate had been neglected prior to his arrival but acknowledges difficulties. Running the Pedlars brand from remote Glen Dye proved difficult and in the winter the road is often blocked by snow, making the logistics of sending out orders very difficult. ${ }^{5} \mathrm{He}$ is critical of the local Council's approach to maintenance and their failure to recognise the importance of infrastructure to businesses. He muses that such obstacles lay behind the decision to move Pedlars to Hawarden and reposition it as an online retailer, because location becomes less important as the business scales. Although his current focus is on his Welsh endeavours, he maintains a number of businesses at Fasque, such as a successful Christmas tree business, an organic farm and a commercial shoot, let on a 21-year lease to a syndicate.

Although life at Glen Dye was not always easy for the nascent entrepreneur, he is aware of how much he learned through the experience. He cites a turning point as the moment, 10 years into his stewardship of the estate when he sacked the entire estate management team. It was a growing up moment when he realised it was down to him. He faced despair but kept going, constantly trying new ideas straddling the fear of boredom, and the adrenaline rush of a good week in business. The idea of simply maintaining the estate is anathema: ' $a$ waste of a life... and so boring...' '.

Hawarden Estate: Charlie has a keen interest in social connectivity. His focus is on existing activities, although he is constantly on the lookout for a new opportunity. To date, he has built a farm shop in Hawarden, refurbished the local pub, the Glynne Arms. He is Chairman of the Trustees of Gladstone's Library in Hawarden, a residential theological research centre, containing the personal library of his great-great grandfather. Charlie is at pains to talk about the professionalism and seriousness with which he executes these activities. At the farm shop, based on a historic pick your own fruit business run by his father, they have hired a well-remunerated management team from Asda, to run the business together with trained butchers on the meat counter which stocks meat from the estate. Initially this was disappointing: around $£ 60,000$ profit this year, but this is growing as the village continues to regenerate. His role at the shop is of Creative Director, where he is in charge of buying, styling, marketing and writing. His dream is to create a unique environment, selling mainly local produce. ${ }^{6}$

Facts and figures roll off Charlie's tongue: the farm shop turnover is $£ 1.75$ million with 48 employees. The butchery takes $£ 10-12,000$ a week while the café takes $£ 6-8,000$ a week, with the average spend being $£ 12.50$. Similarly, he can recall the figures for the pub: it employs 16 people and took $£ 18,000$ in a week, feeding 650 . He laughs about his knowledge of these numbers: 'I'm essentially a creative entrepreneur and I'm not really good at figures. But I like sales figures. Margin I always find harder'. The businesses are funded by bank borrowing. 'We're very cash poor. All these projects are done on borrowed money'. The pub cost $£ 800,00$, the farm shop $£ 400,000$. He believes that he has to be brave to succeed in these enterprises.

Charlie wants to be part of the Hawarden community unlike his father who was a culturally remote figure. Charlie values his potential role in the community and the role of the estate in the coming decades. He talks of enjoying being in his pub and talking to the patrons in a way in which feudal hierarchy doesn't exist. If people complain about their food or experience, he deals with it. He believes that this hands-on approach is necessary for the survival of his estates and to connect with the community - 'We have to take ourselves down from a pedestal.

Charlie maintains an interest in town planning and regeneration, both in the work at Fasque and Glen Dye and in his plans for Hawarden. He cites the Portas pilot towns, where selected towns are given funding to help regenerate, as inspirational in the way that they have involved the local community. The conversation is peppered with references to 'ripple effects' and 'connectivity' and he is keen to create different forms of social connections within the village: to create a lively, kinetic atmosphere. He is proud of the social mix of customers at the farm shop and pub. Charlie is keen to attract locals as well as the more traditional uppermiddle class patrons of such venues targeted towards a very specific demographic, whereas he wants to cater for and encourage a broader customer mix at his enterprises.

Charlie describes the village as being 'slightly down-atheel'. Although relatively close to affluent Chester, it is off the beaten track and is affected by the influx of large supermarkets and bypass roads. With a population of less than 2,000 , it is relatively small, but supports a Post Office, dress shop and hardware store. Charlie refers to it as his 
life's work. His plans are a mixture of micro and macro interventions, ranging from changing the estate colour to improving transportation and facilitating local enterprises. After much battling with local planners, he secured permission to build a carpark in the village. Although a seemingly unexciting project, it is key to encouraging visitors. He draws parallels with Banchory, near Glen Dye, where there is little parking for local shops, forcing customers towards the convenience of the large supermarkets. He complains of 'bloody double lines' everywhere, making the carpark a necessity.

Charlie takes a holistic view of village redevelopment. $\mathrm{He}$ talks of the best community-building developments as being those guided by a single owner, citing Marylebone High Street in London, developed into a retail destination by the owners, Howard de Walden Estates. Although he has had a direct input into infrastructure projects, he sees himself as a guiding influence. He does not want to micromanage but facilitate renovation. He talks of helping nascent businesses by giving them premises rent-free for a period, and of leveraging his business experience and estate resources to help them with bank guarantees and raising finances. Charlie is aware of the dangers of overinvolvement in village affairs and of appearing 'patronising' or a dilettante. It excites him to leave his mark on the village which has a Sunday Times 'best places to live' accolade and to be considered a 'proper entrepreneur'.

\section{Teaching note}

When teaching 'class-based theories of entrepreneurship', it can be difficult to engage middle-class Business School students in the debate because the romance of entrepreneurial narrative has faded somewhat, and its mythic storylines have lost much of their former appeal and resonance. Indeed, in developing and using this case we encountered student resistance. Its use caused considerable heated student debate, most of whom argued vigorously and vociferously against aristocrats being considered entrepreneurs because of their inherited wealth and parental support. Many simply refuse to accept the aristocratic as entrepreneurs. From a perusal of the literature, there are three main questions of interest which this case attempts to address:

- Can upper-class business owners be considered as entrepreneurs?

- Is the traditional view of upper-class estate management as conservative and low-risk still valid, or is there evidence of them pursuing a more enterprising approach to the exploitation and renewal of their estates?

- How does social class influence entrepreneurial social capital and social mobility?
These questions are interrelated because issues of social mobility entail creating social capital and developing an entrepreneurial identity within class systems and socioeconomic strata. Students should work in groups to conduct their own internet research into Charlie, his businesses and estates. This brings the case to life. The discussion points are helpful for teachers in encouraging informed student discussion. There are no right or wrong answers and because this case invokes strong class-based responses from students, teachers may be unable to convince them that Charlie deserves the title or status of entrepreneur. We acknowledge that social class in this case is constrained by UK perspectives on class which has wider international attraction in relation to social mobility because entrepreneurship as a way of creating social mobility is universal and cuts through social context. The social mobility context illuminates the 'so what' of the case and ideas of aristocratic enterprise because entrepreneurship as a mechanism enables social mobility and the phenomenon of upwards and downwards mobility and comparative differentials around wealth creation between classes and geographic contexts. Thus, social mobility in the context of this case differs significantly from such mobility in rural Bangladesh or women in Africa as compared with poverty-stricken areas of UK. Moreover, social mobility is context specific (e.g. as a route out of poverty or as a mechanism to sustain upper class wealth) and is dependent upon a myriad of socio-economic and socio-demographic factors. This note allows students to research and challenge their understanding of the topics and test other social contexts through entrepreneurship. Accordingly, facilitators are encouraged to build in 'teaching pathways' around the questions or touchpoints in the case with the starting point being either class-based theories or social mobility. The following questions relate to class-based theories of entrepreneurship, entrepreneurial identity and social mobility and additional ideas for student led research.

Point 1 'Entrepreneurial motivation': So, what drives Charlie? He is definitely upper-class and aristocracy - fitting all the definitions. Yet he is a serial entrepreneur, constantly looking for another project. But it's not just about making money, he focuses on the contradiction of why someone in his position, with a large inheritance, feels the need to make money. Unlike the traditional model of rentier-capitalism, the Gladstone family no longer rely solely on rent-seeking to finance family life. Their combined entrepreneurial ventures generate incomes to provide substantial inheritances for all six children. He is not an isolated example and many of his peers are well known specifically online and mail order - lifestyle and clothing companies, such as Cox \& Cox, Not on the High Street, Charles Tyrwhit, Boden, The White Company and Jack Wills. All are public school educated. He doesn't ascribe their success in business to their social networks and interconnectedness, but to a sense of entitlement, confidence 
and self-belief. Charlie believes that it is an innate ability to believe you are entitled which supersedes confidence. He brims with self-confidence and a determination to make things happen. Charlie and his immediate family are products of his and their upbringing and of the socially constructed nature of social class with its inherent element of entitlement.

Suggested question: What do you understand social mobility to mean to you and how might entrepreneurship and 'being' entrepreneurial cut across socio economic strata?

Point 2 'Entrepreneurial Confidence': Underpinning his confidence is a determination to prove himself, a trait he sees in his peers also. He is not happy living on inherited wealth and is aware that this can be seen as arrogance, but views this in a positive light in comparison to maintaining the status quo and managing the estates in the traditional manner of previous generations because he is bigger and better than that. With the conservative rental income of two large estates, Charlie could quite easily have settled for a life of low-risk estate management: farming, forestry, commercial shoots. While these activities form part of his portfolio of businesses, they don't excite him like his creative entrepreneurial ventures, his retail operations, the farm shop, the Glynne Arms, his charitable work and his stewardship come social engineering at Hawarden village, and Glen Dye. His entrepreneurial horizons are expanding.

Suggested questions: What social class are you and how might this influence your entrepreneurial identity or social capitals? How might a class system influence your social capital? Do you think entrepreneurial confidence builds social capital?

Point 3 'Is class as an entrepreneurial context relevant?' Attempting to define class, is problematic. Charlie acknowledges that he is unsure of the difference between middle and upper-class anymore, despite being an aristocrat. His membership of the aristocracy and that of Jacks future family is guaranteed through peerage. Family survival is guaranteed by estate income. Charlie sees more of a generational shift in attitude towards engagement between his father's generation and his own. His father used his formal title - Sir William. Charlie, is a much more approachable, informal character at his happiest mixing with the locals at his pub. During the interview and follow-ups, Charlie never referred to himself as being upper-class, preferring the terms entrepreneur, or creative entrepreneur (pronounced in French).

Suggested questions: Do you agree with Charlie's logic in relation to his use of the term entrepreneur. Is it incongruent in relation to entrepreneurial ideology?

Point 4 on aristocratic entrepreneurial identity: Charlie also derives professional identity through occupation, rather than family connections. Echoing the findings of Anderson and Jack (2000), Charlie seems to seek prestige and status through his entrepreneurial identity which in previous generations would have been anathema to other aristocrats. He is proud of his identity as a 'new rural landowner' (Gill et al., 2010). Charlie draws identity from his inhabited landscapes - Wales, Scotland and London - and demonstrates an enlightened view towards sustaining and exploiting them. Particularly in Hawarden, he is keen to extend access to the estate while increasing paternalistic support to the reinvigorate the village. Rather than relying on state intervention, he adopts an entrepreneurial approach to the village renovation for the public good. He acts as a catalyst for the village project. By becoming more socially integrated within his community, he provides support through the assets of the estate, whether financial or social, to help fuel the estate redevelopment. Although potentially radical when viewed against his landowning peers, this model harks back to the manor house estate model whereby the site of influence (the house itself) was linked to the village and involvement in the day-to-day village activities than the later model which saw the upper-classes retreat to their bounded estates. Although his identity forms around his businesses and his estates, Charlie's motivation - and need to make his mark - was inculcated at Eton. Aware of being seen as arrogant he is keen to put himself in the public eye, despite occasional public disapprobation. ${ }^{7}$

Suggested questions: What do you understand entrepreneurial identity to mean to you and how might this influence your own entrepreneurial identity? Why is it important? How might entrepreneurial identity be shaped and influenced by where you were born, your culture, your education, your parents and your peer group?

Point 5 on entrepreneurship as a mechanism for social mobility: Charlie utilises entrepreneurship and its ideology as a mechanism for maintaining an already established mobility position. He acknowledges that he could live off the rents from existing estates but wants to create and extract further value from his environments for the sake of his family which is the very definition of entrepreneurship as argued by Anderson (1995). He is well aware of the plight of other aristocratic families who have been forced to sell their estates and the proverbial family silver to avoid downwards mobility. While the Gladstones may not be a typical upper-class family, they are excellent role models of contemporary aristocratic enterprise. Unlike traditional entrepreneurs, who develop a business to sell, the estates exist in perpetuity and the business model must of necessity evolve too. Traditionally, the right of primogeniture would pass on the estates and baronetcy to the first-born. However, Charlie suggests that as a modern family, the running of the Estates might go to his eldest daughter or whoever is most suited. He has no succession plans, relishing an entrepreneurial future.

Suggested question: Having developed an understanding of what social mobility means to you how does your position differ from other social contexts relating to social mobility and classes in different countries? 
Point 6 on researching entrepreneurial identity Other examples of upper-class entrepreneurs pursuing more innovative enterprises include Lord March at Goodwood and the Duchess of Northumberland at Alnwick, Deborah Cavendish, Charles Gordon-Lennox, Charles March and Richard Dinnan.

Suggested student activities: 1) Students could be encouraged individually or in groups, to research other examples and provide a justification of whether they can be considered entrepreneurial, or not? What connections can be drawn between innovative upper-class entrepreneurs and their use of capital, land and resources? 2) Additionally, students should challenge their own entrepreneurial identity and social capitals in terms of a reexamination of social mobility in terms of creating and developing their personal networks, building relationships and navigating social constraints

\section{Theoretical underpinning}

This review of literature on class and enterprise provides a theoretical context against which students can analyse the case and assembles appropriate literature. However, best results are achieved if students are allowed to read the case before developing their theoretical understanding. The literature surrounding class and enterprise in Britain is sparse for a country stereotyped as being obsessed with class and class stratification. There are two main schemes of class the 'working-class entrepreneur' and the 'entrepreneurial middle classes' (Smith et al., 2014). The middle classes are an entrepreneurial niche (Scase and Goffee, 1982), yet the overwhelming thrust has been about the myth of the working-class, poor-boy-done-good, typified by a raft of biographies and television programmes focusing on the romanticised tales of the rags-to-riches tales of successful entrepreneurs where success is measured through acquisition of expensive houses, cars, yachts and other indicators of wealth.

To a certain extent, entrepreneurship facilitates social mobility (Lippmann et al., 2005), yet there is a still a class ceiling (Friedman and Laurison, 2019) whereby access to the upper-class is restricted and codified. Exactly what those codes are is unclear, as access to them is difficult, and, as such, they are difficult to research empirically (Reid, 1989). Aristocrats are seldom discussed in relation to social mobility and in particular how this relates to entrepreneurial identities or social capitals. Although overlooked in business literature, historians have written persuasively on the relationship between the upperclasses and entrepreneurship, particularly Thompson (2001). ${ }^{8}$ It focuses on the grand industrialists of the Victorian period, and their (partial) integration into the upperclass (See also Thompson, 1988). Landowning, farming and property ownership are viewed as traditional forms of low-risk enterprise undertaken by the established upper-classes. This is indicative of 'Rentier Capitalism' or living off the proceeds of rental income - although derided as a non-productive form of capitalism, is a traditional activity of landowners, together with the establishment of property portfolios (Pollin, 2007; Standing, 2017). Many such landowners farm their land directly and through tenant farmers, and have been forced, through necessity, into engaging in pluriactivity and diversification activities (McElwee and Bosworth, 2010). Mandler (1997) articulates the pressures or necessity of the increasingly "poverty stricken' upper-class to commercialise access to their houses and estates to fund survival, yet there is little literature covering pro-active upper-class entrepreneurs, who create enterprises for other reasons. This is important because the upper-class also have a motivation to grasp entrepreneurial opportunities (Stephan et al., 2015). There is an increase in interest in upper-class entrepreneurship (See Fellowes, 2008). ${ }^{9}$

Definitions of class are subject to change over time. Various arguably simplistic schemas have been proposed mainly centred on occupation (Szreter, 1984). The EriksonGoldthorpe-Portocarero (EGP) model and the National Statistics Socio-Economic Classification (NS-SEC) draw a more fine-grained difference between occupations than earlier model of the Registrar General's Class schema. ${ }^{10}$ Defining the aristocracy and landed-gentry, has historically been relatively easy. Membership of the Peerage (a hereditary title) assumes membership of the aristocracy, as does membership of the gentry (Burke's Landed Gentry, 2012). Thompson (2001) suggests that ownership in excess of 2,000 acres is a reasonable indicator of such status. Defining the wider upper-class becomes harder, including the non-landed gentry, minor branches of families and intermarriage between classes. The BBC class survey posited a new definition of the 'elite class' to supersede the upperclass. The elite have 'very high economic capital (especially savings), high social capital, very high highbrow cultural capital' (Prandy and Jones, 2001; Savage et al., 2013). ${ }^{11}$ While CAMSIS is validated as an occupational scale, there is a fascinating anomaly - not only are there no scores available for those that have never worked and those that are students, there is no score for the aristocrat. As such, within these proposed social strata the aristocracy is denied a unique entrepreneurial identity. This absence of the aristocrat poses an interesting contradiction because historically, aristocrats did not need to work and living off independent rental income was prized. Charlie is entrepreneurially prodigious.

Other definitions draw on indicators of class, such as its socially constructed nature (Crompton, 2008). Bourdieu (1986) defines three types of capital: economic, cultural and social and how examination of these can help create a much more complex and detailed understanding of the nuances of class. It is helpful to define upper-classness as being land-rich but cash poor, but rich in cultural and 
specifically social capital. The findings of Anderson and Miller (2003) show the practicable application of Bourdieun theory. For them, the established entrepreneurial middle-classes are at an advantage in creating, sustaining, and growing, enterprises through the high endowments of human and social capital they are able to draw upon at critical moments in the lifetime of an enterprise as may be the case with the upper-class and aristocracy.

Nonetheless, this search for identity or meaning has been previously expressed as part of the personality theory of entrepreneurship and while status and achievement are not synonymous, there may be more than a passing link between the two. Identity can be framed in terms of rurality and relation with the environment. Marsden (1998) articulates four ideal-typical types of rural spaces: the preserved, contested, paternalistic and clientelistic countryside. Much of Scotland and Wales is clientelistic - dependent on state subsidy for survival. Gill et al. (2010) define what they term the 'new rural landowners' to characterise landowners who have shifted from traditional agricultural practices to new forms of pluriactivity. They define new landowners as having 'limited, if any, dependence on farm income, relatively high interest in environmental stewardship, small-scale farming operations, sub-commercial landholdings, and a focus on landownership for lifestyle reasons'. This form is less rule-bound and entrepreneurial than previous generations (Wilson, 2008).

\section{Postscript and concluding the case}

Charlie cannot be seen as representative of an entire new breed of upper-class entrepreneur, nor are the conclusions drawn universally representative. Future case studies will provide a more detailed picture of the influences, motivations and practices of this overlooked class within the entrepreneurship and business literature. Nevertheless, this is an intriguing case. With a personal identity centred on being a creative entrepreneur and a drive to succeed and be recognised shaped by the Machiavellian, competitive environment of Eton, Charlie presents as a persuasive figure. The scope and creativity of his activities address the research questions posed. His membership of the upper-class should not disqualify him from being an entrepreneur because social class is just another context (Gaddefors and Anderson, 2018; Jones et al., 2019a, 2019b) in which entrepreneurship can be enacted albeit he is the antithesis of the remote, traditionalist aristocrat. The case provides a richly detailed insight in the world of the modern landowner and landed entrepreneur. While the traditional activities of farming and forestry and low-risk diversification may well still be the norm of most upper-class landowners, this case evidences a more enterprising and more socially engaged entrepreneurial approach, worthy of further study. It challenges the common UK class-based perception that to be aristocratic is to be anti-entrepreneurial and that the best model of income generation is rentier capitalism. Charlie is an aristocratic landowner, rentier and entrepreneur. This case enhances our understanding of the connections between entrepreneurial identities and contexts in influencing entrepreneurial behaviour and how it is perceived. It also extends current thinking. In relation to the criticism of entrepreneurship as an individual endevour this case demonstrate that although Charlie's story is a very patriarchal and parochial entrepreneurial narrative the way he narrates it as a family affair is progressive. The analysis demonstrates that the enriched human, social and economic capital available to the upper-class can be exploited in an entrepreneurial manner and applied not just to the creation of new enterprises, but to the (re)construction of place. This case contributes by extending existing theories of entrepreneurship and class to demonstrate the practical application of entrepreneurship outside its traditional domain.

\section{Declaration of conflicting interests}

The author(s) declared no potential conflicts of interest with respect to the research, authorship, and/or publication of this article.

\section{Funding}

The author(s) received no financial support for the research, authorship, and/or publication of this article.

\section{ORCID iD}

Rob Smith (D) https://orcid.org/0000-0002-8929-4804

\section{Notes}

1. This case formed part of the first authors doctoral study into estate management. One interview with the respondent lasted over 2 hours. It was audio-recorded and transcribed as is common practice. This was followed up by telephone interviews to clarify important emergent themes and augmented by accessing newspaper articles and websites. Personal communications helped contextualise and triangulate data.

2. Without access to the necessary forms of capital (human, social and financial) it is difficult to gain entry to the elite (Mandler, 1997; Savage et al., 2013). Accordingly, cultural admittance to the upper-class itself remains difficult (Reid, 1989). For the researcher, this can prove problematic in the generation of meaningful data. The statistically low numbers of aristocratic entrepreneurs in the UK make most forms of quantitative analysis redundant, as sample sizes will be too small.

3. Students interested in a fuller family history and the evolution of the Baronetcy can obtain this from the authors or access it as additional data from the authors Research Gate profile on the website.

4. Two sons and four daughters, Jack William, India Kate, Tara Rosamund, Xanthe Flora Mali, Kinvara Rose and Felix Louis Nesta. 
5. For example, he has to corral local four-wheel drive vehicles to take their deliveries to the local post office.

6. Although they sell foreign wine and pasta, they sell no foreign cheese, believing British is best.

7. E.g. vitriolic threads on website Mumsnet about Pedlars and his class background. This public attitude is seen more broadly in relation to his friends and peers - fellow Etonian Johnnie Boden, who Charlie confides finds public disapproval upsetting. As Charlie points out, many founders of high-end successful retail ventures, are all public school educated.

8. In his seminal book 'Gentrification and the Enterprise Culture'.

9. See the newspaper article of the journalist Jessica Fellows 'Posh-preneurs who mean business'.

10. These schemes tend to exclude the elite or upper-class, due to small sample sizes in those categories.

11. They suggest a new set of class strata of: The Precariat, Emergent Service Workers, Traditional Working Class, New Affluent Workers, Technical Middle Class, Established Middle Class and the Elite. Status scores were drawn from a list of 37 occupations, coded to the Cambridge Social Interaction and Stratification scale [CAMSIS].

\section{References}

Anderson AR (1995) The Arcadian Enterprise: an enquiry into the nature and conditions of rural small business. Unpublished PhD Thesis, University of Stirling, UK.

Anderson AR and Jack SL (2000) The production of prestige: An entrepreneurial viagra. The International Journal of Entrepreneurship \& Innovation 1(1): 45-61.

Anderson AR and Miller C (2003) Class matters: human and social capital in the entrepreneurial process. Journal of Social Economics 32(1): 17-36.

Bourdieu P (1986) The forms of capital. In: Richardson J (ed.) Handbook of Theory and Research for the Sociology of Education. New York: Greenwood, pp. 241-258.

Bourdieu P (1997) The forms of capital. In: Halsey A, Lauder H, Brown P, et al. (eds) Education: Culture, Economy and Society. Oxford: Oxford University Press.

Burke's Landed Gentry (2012). Available at: http://www.burke speerage.com (accessed 5 June 2018).

Burt K (2010) Build it and they will come: Family-run company Pedlars is marketing a whole lifestyle. The Independent, 30 July. Available at: http://www.independent.co.uk/property/ house-and-home/build-it-and-they-will-come-familyrun-com pany-pedlars-is-marketing-a-whole-lifestyle-2039023.html (accessed 12 March 2018).

Cannadine D (1977) The landowner as millionaire: the finances of the Duke of Devonshire, C1800-1926. Agricultural History Review XXV: 79-82.

Crompton R (2008) Class and Stratification, 3rd ed. Cambridge: Polity Press.

Drakopoulou Dodd S and Anderson AR (2007) Mumpsimus and the mything of the individualistic entrepreneur. International Small Business Journal 25(4): 341-360.
Fellowes J (2008) The 'posh-preneurs' who mean business. Available at: http://www.telegraph.co.uk/finance/newsbysector/ retailandconsumer/3118179/The-posh-preneurs-who-meanbusiness.html\# (accessed 25 November 2020).

Firkin P (2003) Entrepreneurial capital. In: De Bruin A and Dupuis A (eds) Entrepreneurship: New Perspectives in a Global Age. Aldershot: Ashgate, pp. 57-75.

Friedman S and Laurison D (2019) The Class Ceiling. Bristol: Policy Press.

Gaddefors J and Anderson AR (2018) Romancing the rural: reconceptualizing rural entrepreneurship as engagement with context(s). The International Journal of Entrepreneurship and Innovation 20(3): 159-169.

Gill NJ, Klepeis P and Chisholm LA (2010) Stewardship among lifestyle oriented rural landowners. Journal of Environmental Planning and Management 53(3): 317-334.

Goffe R and Scase R (2015) The Entrepreneurial Middle Class. London: Routledge.

Grant GAI (2020) The identification and exploitation of entrepreneurial opportunities on family owned estates in the north-east of Scotland. Unpublished PhD thesis, Robert Gordon University, Aberdeen.

Jones P, Ratten V, Klapper R, et al. (2019a) Entrepreneurial identity and context: current trends and an agenda for future research. The International Journal of Entrepreneurship and Innovation 20(1): 3-7.

Jones P, Ratten V, Klapper R, et al. (2019b) Emerging themes in entrepreneurial behaviours, identities and contexts. The International Journal of Entrepreneurship and Innovation 19(4): 233-236.

Lippmann S, Davis A and Aldrich HE (2005) Entrepreneurship and Inequality. In: Keister LA (ed) Entrepreneurship (Research in the Sociology of Work, Vol. 15). Bingley: Emerald Group Publishing Limited, pp. 3-31.

Mandler P (1997) The Fall and Rise of the Stately Home. London: Yale University Press.

Marsden T (1998) New rural territories: regulating the differentiated rural spaces. Journal of Rural Studies 14(1): 107-117.

Martinelli A (2004) The social and institutional context of entrepreneurship. In: Corbetta G, Huse M and Ravasi D (eds) Crossroads of Entrepreneurship. London: Kluwer Academic Publishing.

McElwee G and Bosworth G (2010) Exploring the strategic skills of farmers across a typology of farm diversification approaches. Journal of Farm Management 13: 819 - 838.

Mee G (1975) Aristocratic Enterprise: The Fitzwilliam Industrial Undertakings, 1795-1857. Glasgow: Blaikie \& Sons, Ltd.

Mingay GE (1963) English Landed Society in the Eighteenth Century. London: Routledge.

Pittaway L and Cope J (2007) Simulating entrepreneurial learning: integrating experiential and collaborative approaches to learning. Management Learning 38(2): 211-233. 
Pollin R (2007) Resurrection of the rentier. New Left Review 46: 140-153.

Prandy K and Jones FL (2001) An international comparative analysis of marriage patterns and social stratification. International Journal of Sociology and Social Policy 21: 165-183.

Reid I (1989) Social Class Differences in Britain - Life Chances and Lifestyles. Fontana, CA: Fontana Press.

Savage M, Devine F, Cunningham N, et al. (2013) A new model of social class? Findings from the BBC's Great British Class Survey experiment. Sociology 47(2): 219-250.

Scase R and Goffee R (1982) The Entrepreneurial Middle Class. London: Croom Helm.

Smith R, Grant G, Gibbons-wood D, et al. (2014) Towards a Typology of British Upper-Class Entrepreneurship. Unpublished seminar paper.

Standing G (2017) The Corruption of Capitalism: Why Rentiers Thrive and Work Does Not Pay. London: Biteback Publishing.
Stephan U, Hart M and Drews CC, (2015) Understanding Motivations for Entrepreneurship. Birmingham: Enterprise Research Centre.

Szreter R (1984) The genesis of the Registrar General's social classification of occupations. British Journal of Sociology 35: 522-546.

Thompson FML (1963) English Landed Society in the Nineteenth Century. London: Routledge.

Thompson FML (1988) The landed aristocracy and business elites in Victorian Britain. Actes du Colloque de Rome 107: 21-23. novembere, 1985, 267-279.

Thompson FML (2001) Gentrification and the Enterprise Culture: Britain 1780-1980. Oxford: Oxford University Press.

Weber M (2013) Economy and society, Roth G and Wittich C (eds). Oakland: University of California Press.

Wilson GA (2008) From 'weak' to 'strong' multifunctionality: conceptualising farm-level multifunctional transitional pathways. Journal of Rural Studies 24(3): 367-383. 